удК 349.2

DOI https://doi.org/10.32837/pyuv.v1i4(29).390

\section{О. М. Нестеренко orcid.org/0000-0001-5661-7083 кандидат юридичних наук,} старший викладач кафедри публічного управління, адліністрування та права Таврійського державного агротехнологічного університету імені Дмитра Моторного

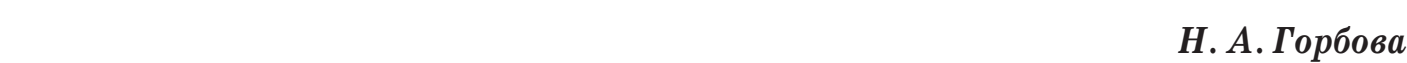
orcid.org/0000-0003-1428-895X кандидат педагогічних наук, доцент кафедри публічного управління, адміністрування та права Таврійського державного агротехнологічного університету імені Дмитра Моторного

\title{
ТЕОРЕТИКО-МЕТОДОЛОГІЧНІ МЕХАНІЗМИ ВПЛИВУ ДЕРЖАВНОЇ ПОЛІТИКИ НА ПРОЦЕС ФОРМУВАННЯ СВІДОМОЇ ОСОБИСТОСТІ
}

Одним із головних факторів, який визначає специфіку правового виховання у різних типах правових систем світу, на наш погляд, є панівна у державі ідеологія. Як свідчить вся історія становлення та розвитку людської цивілізації, державна влада завжди передбачає ідеологічну регуляцію суспільного життя, від помірного впливу певних ідей на суспільно-політичні процеси до існування повністю детермінованих ідеологічними системами держав (теократичних, комуністичних тощо) [1, с. 292]. Ще античні філософи докладно писали про роль ідей у житті держави, необхідності виховання громадян у дусі відданості батьківщині, самопожертви. Типи державної ідеології, наприклад, в Афінах і Спарті, суттєво відрізнялися, зумовлюючи тим самим різні характеристики базисного типу особистості - в одному випадку громадянська активність і політична культура громадянина, в іншому - ж суто військові чесноти [2, с. 139].

Підкреслюючи важливість існування ідеології для стабільної життедіяльності соціуму, O.I. Заздранова вказує, що вона виступає джерелом соціальної мотивації для індивідів, а також виконує надзвичайно важливу функцію легітимації всього, з чим вона має справу у змістовому плані: уявлень про світ і місце людини в ньому, певних форм соціальної організації, соціальних відносин, типів поведінки і способу життя [3, с. 7]. Польська дослідниця Б. Дубер визначає три головні функції національної ідеології: селективну (поділяє членів спільноти на угруповання прихильників певної ідеології), інтеграційну (притягує групи спільноти до сповідування певної ідеологічної орієнтаціі) і виховну (пропагує певний вид поведінки, цінності та норми) [4, с. 41-43]. Вважаємо, що вказані функції притаманні не лише національній, а й іншим різновидам ідеології: релігійній, політичній, державній, правовій.

Щоправда, правова ідеологія має певну специфіку, на що у науковій літературі вже зверталася увага. Зокрема, М. Недюха пише, що правова ідеологія має моністичний характер, оскільки іï сутність зумовлюється нормою права, на відміну, скажімо, від політичної ідеології, яка завжди $€$ плюралістичною, оскільки грунтується на певних інтересах - групових, корпоративних чи суспільних [5, с. 300]. Водночас існує безпосередній зв'язок між правовою та політичною ідеологією. Політична ідеологія - це система концептуально оформлених уявлень, ідей і поглядів на політичне життя, яка відображає інтереси, світогляд, ідеали соціальних класів, націй, різних суб'єктів політики. Структурними елементами політичної ідеології є політичні теорії та ідеї, концепції політичного розвитку, соціально-політичні ідеали, цінності, політичні програми, символи тощо [6, с. 108]. Усі ці елементи неминуче відображаються у законодавстві держави, тобто стають частиною правової ідеології. За словами I.I. Кравченка, закон - це аспект матеріалізації панівної ідеології та фундаментальна категорія державного суверенітету. Він виконує і функції легітимації, замінює відсутню або невиражену ідеологію, дає формулювання спільних цілей, історичних завдань суспільства, обгрунтовує ідеологію будь-якого розвитку, майбутнього тощо. Він сам стає своєрідною ідеологією, покликаною формувати соціальну єдність [7, с. 53]. O.I. Клименко також вказує, що ідеологія держави є соціально-політичною за своєю природою, як і будь-яка ідеологія, і правовою по своїй суті [8, с. 37]. Саме ідеологія дозволяє забезпечити єдність ціннісних орієнтацій індивіда і держави, інтегрувати всю множину соціальних, конфесійних, територіальних, етнічних та інших груп у дещо ціле, самоідентифікація з яким є для індивіда суб'єктивно значимою [2, с. 114].

Панівна у державі ідеологія багато в чому визначає характер правосвідомості, правової культури, а відтак - і правового виховання, спрямованого на прищеплення громадянам відповідних 
цінностей i думок. Найбільш потужним вплив ідеології на свідомість населення є у державах недемократичного вектору розвитку. Наприклад, у мусульманських країнах навіть статус тієї чи іншої науки залежить від оцінки їі корисності для релігії ісламу. Ще з XII-XIII ст. склалася практика, згідно з якою астрономія, арифметика і геометрія оголошувалися «корисними», оскільки для здійснення молитви кожному мусульманину необхідно було знати точний час і напрям на Мекку. Інші ж науки, насамперед природні та філософія, критикувалися як непотрібні або такі, що підривають справжню картину пізнання світу. Офіційно визнана державою ісламська наука концентрувалася в мусульманських центрах освіти (медресе) і зосереджувалася на вивченні Корану, життя Пророка і його послідовників, дедалі більше занурюючись у вирішення внутрішніх богословських суперечностей (наприклад, обгрунтування сунітської або шиїтської концепції влади). Незалежна арабська наука ставала або глибоко особистою справою, або переходила в розряд «придворних", як, наприклад, астрологія і медицина $[9$, c. 20$]$.

У державах із тоталітарним режимом вихованню «правильного» мислення приділяється велика увага. Наприклад, К.С. Гаджиєв акцентує на тому, що найважливішим компонентом тоталітаризму є ідеологічний монізм, який пронизує всю ієрархію владних відносин зверху донизу. Єдина універсальна мета зумовлює єдину моно-ідеологію в особі державної ідеології та сконструйовані на її основі політичні орієнтації, установки, принципи, які за допомогою розгалуженої комунікаційної мережі наполегливо впроваджуються у масову свідомість. Ці установки покликані обгрунтувати і пояснити реальну дійсність у термінах цієї мети, подолати перешкоди на шляху до неї, для чого використовуються всі засоби, в т. ч. пропагандистські і виховні. Усе. що не узгоджується 3 однодумністю щодо даної мети, піддається анафемі та ліквідується. Наслідком цього є прагнення держави до трансформації людини відповідно до панівних ідеологічних установок, конструювання нового типу особистості з особливою ментальністю, поведінковими та інтелектуальними характеристиками [10, с. 15]. Часто за таких умов як інструмент впливу на свідомість громадян використовують правову демагогію, яку В.М. Баранов визначає як навмисний (іноді обманний) вплив на почуття і знання людей за допомогою різних форм односторонньої або грубо спотвореної подачі правової дійсності для досягнення власних цілей, зазвичай приховуваних під виглядом користі для народу і добробуту держави [11, с. 22-23].

На відміну від цього, у демократичних країнах ідейний плюралізм $є$ необхідною умовою політичного життя, своєрідним конституційно закріпле- ним і гарантованим державою індикатором, за яким, власне, i можна судити про ступінь реальної демократичності суспільства. Неминучим наслідком його є багатопартійність, політична боротьба, легітимні форми конкурування приватних ідеологій [2, с. 122]. Попри наявність у демократичних державах альтернативних ідеологічних підходів до різних питань, можна говорити також про формування єдиної, інтегративної ідеології демократичного суспільства. Демократична ідеологія обгрунтовує та зміцнює у свідомості людей природно-правові та гуманістичні ідеї, переконує ї у необхідності дотримання режиму законності та правопорядку. Основною метою такої ідеології є формування громадянського суспільства та правової держави. Вона тісно й органічно пов'язана 3 правовою психологією, враховує традиції, настрої та емоції людей. Демократична ідеологія - це частина демократичної правосвідомості [6, с. 106]. Оскільки характерною рисою сучасної демократії $€$ не тільки дотримання прав більшості, але і повага до прав меншості, виховання поваги до прав меншин є важливою складовою частиною сучасного процесу правового виховання у демократичних державах.

Важливим проявом ідеологічного впливу на свідомість громадян $є$ патріотичне виховання. А.Г. Мовсесян відзначає, що не можна збудувати сильну державу без виховання у громадян почуття патріотизму, почуття значимості дії конкретної людини в житті своєї країни, почуття причетності до проблем свого народу, і ці завдання належать до функцій державної ідеології [12, с. 3].

Стан і характер виховання молодого покоління визначаються економічними, соціальними, культурними та історичними умовами суспільного розвитку, які склалися в різних країнах. Підходи до розвитку патріотизму у громадян на кожному етапі становлення і розвитку тієї чи іншої держави зазнають змін відповідно до розроблених і прийнятих філософських концепцій, педагогічних теорій, а також вимог суспільства до організації виховної діяльності. Попри те, що патріотизм $€$ універсальним явищем, у різних типах правових систем є різні підходи до його виховання. Наприклад, у державах, для яких характерна англосаксонська модель молодіжної політики, панує підхід підтримки виключно добровільної діяльності молоді, без системної участі держави. У Великій Британії патріотичне виховання побудоване на ознайомленні з військово-історичними традиціями, популяризації армійської служби. Важливу роль у прищеплені патріотизму британській молоді відіграють скаутські загони. Принцип КАРЕ (тримати армію під наглядом населення), який діє у країні, сприяє підняттю патріотичного духу серед молоді. У Великій Британії створено розгалужену систему центрів і програм, зокрема Об'єднані 
сили кадетів, Армійські сили кадетів, Морський кадетський корпус та ін. До навчання в таких кадетських центрах залучаються представники Міністерства оборони, офіцери запасу, добровольці та інші зацікавлені особи. Відвідування центрів при школах є добровільною справою. Школярів навчають не лише військовій справі, а й історії війн, соціальним наукам, основам держави [13, с. 2-3]. У США найвпливовішими суб'єктами патріотичного виховання також є організації скаутизму: бойскаути Америки, які налічують близько 3,8 млн членів; відділення Всесвітньої асоціації дівчат-провідників і дівчат-скаутів (World Association of Girl Guides and Girl Scouts); молодіжні організації: «Молода Америка»; «Молоді американці за свободу» $[14$, с. 56]. Незважаючи на те, що провідна роль у підготовці офіцерів у США відводиться військовим училищам, найбільш численним (за кількістю випускників) джерелом поповнення офіцерського корпусу є цивільні навчальні заклади, які здійснюють позавійськову підготовку на підставі закону про національну оборону, що передбачає створення військових відділів при середніх і вищих навчальних закладах.

На відміну від цього, європейська модель молодіжної політики характеризується більш централізованою системою виховання патріотизму. Щоправда, сам термін «патріотизм» у європейських країнах майже не вживається. Наприклад, німецькі педагоги, остаточно засудивши ідеологію нацизму, перестали вживати термін «патріотизм», оскільки в часи Другої світової війни цей феномен асоціювався у них з відданістю фюреру i Рейху [15, с. 139]. Його виховання було замінено вихованням громадянськості - нової інтегративної якості особистості, що сприяє соціалізації молодих людей в умовах сучасного світу. Громадянськість визначається як духовно-моральна цінність, світоглядно-психологічна характеристика людини, зумовлена їі державною самоідентифікацією [16]. Це складне особистісне утворення, яке включає в себе почуття поваги та любові до рідної країни, політичну і моральну відповідальність, правову культуру, усвідомлення власної гідності, повагу і довіру до співгромадян. Громадянськість має ціннісно-смислову природу і проявляється у єдності громадянської свідомості та громадянської поведінки. Тобто вона повинна проявлятися не тільки в усвідомленні своєї належності до країни, а й у активних діях, спрямованих на виконання своїх громадських обов'язків перед суспільством і державою. Громадянськість виступає критерієм особистісної зрілості. Громадянськість пов'язана також із формуванням розвинутої правосвідомості, законослухняності, правової культури.

У Франції виховання громадянськості є важливою складовою частиною шкільного навчаль- ного процесу. У школах Франції проводяться спеціальні уроки громадянської освіти, на яких розповідають про ідеї рівноправності, соціальної справедливості, свободи особистості. У початковій школі діти дізнаються про місце Франції у сучасному світі, а також вивчають слова «Марсельєзи» . У середній школі знання про країну поглиблюються. Більш того, змалечку діти знають багато інформації про французьку армію, національну безпеку. На законодавчому рівні закріплено, щоб на фасадах будівель шкіл були прапори Франції та девіз «Свобода, Рівність, Братерство» [17].

У Німеччині на питання: «Що потрібно для того, щоб бути справжнім громадянином своєї Батьківщини?», дається така відповідь: поважати й дотримуватися прав і свобод людини та громадянина; вчити, досліджувати, розуміти історію своєї Батьківщини; дотримуватися правил i норм поведінки, які діють у сучасному демократичному суспільстві; розуміти й брати участь у життєдіяльності державних інститутів; розвивати свої розумові здібності; формувати своїм прикладом оточення (суспільство), в якому панує толерантність (терпимість), людяність, взаємодопомога, підтримка, справедливість, чесність, наполегливість, воля. Сучасна німецька педагогіка стимулює участь підростаючого покоління в управлінні країною, адже це є основною функцією громадянина в демократичному суспільстві; а також намагається підвищити активність молоді в недержавних організаціях, рухах, які сприяють розбудові громадянського суспільства [15, с. 140-141].

Республіка Польща також має значні напрацювання у сфері патріотичного виховання населення. Так, польським урядом розроблена і реалізується програма, яка має назву «Патріотизм завтрашнього дня». Відповідно до неї у різних містах Польщі місцева влада влаштовує дні національного прапора. В агітаційних роликах на телебаченні та на радіо лунають пісні, які обіцяють, що Польща перетвориться на державу, яка базуватиметься на принципах верховенства права, солідарності та справедливості. Програма спрямована здебільшого на молодих людей, котрих закликають залишатися на Батьківщині та будувати тут своє майбутнє. Патріотичне виховання у Польщі розпочинається з дошкільного віку. Дітей ще із садочка вчать, як виглядає прапор, вчать національного польського гімну, виховують у них локальний патріотизм. Дошкільнят водять по музеях рідного міста, показують пам'ятники, знайомлять із місцевими героями, 3 місцевими традиціями. Дитину вчать розуміти, ким вона є, пізніше її почуття патріотизму розширюється до містечка, згодом до воєводства і врешті - до держави загалом. Можна сказати, що цей досвід відповідає трьом етапам патріотичного виховання, 
які виокремлює О. Вишневський: 1) формування раннього етнічного самоусвідомлення, яке розпочинається в родині шляхом передачі традицій та обрядів; 2) національно-політичне самоусвідомлення, що відбувається під впливом усвідомлення соціального життя, вивчення історії та культури; 3) державно-політичне самоусвідомлення, формування почуття причетності до своєї нації і розбудова власної державності [18, с. 97].

Показовим стосовно ідеологічного впливу на процес патріотичного виховання молоді є приклад Китаю. Велику увагу патріотичному вихованню приділяють органи державної влади КНР. Останнім часом збільшилася кількість патріотичних матеріалів у ЗМІ та Інтернеті, в партійних виданнях частіше стали з'являтися звернення до молоді патріотичної спрямованості. Помітною у цьому напрямі є діяльність Комуністичної партії Китаю та Комуністичного союзу молоді Китаю. Як наслідок, серед молоді дедалі більш популярною стає думка про те, що західна демократія суперечить китайським духовним цінностям, і що для Китаю основним завданням нині є фізичне виживання народу, проведення економічних реформ, а не свобода вираження думок. Парадигма патріотичного виховання Китаю будується на принципі: «Не забудемо, не пробачимо національного приниження». Часто пригадується той факт, як на початку минулого століття над входом у Британські Публічні сади в Шанхаї було встановлено табличку «Собакам і китайцям вхід заборонено». Сьогодні ця національна реліквія урочисто виставлена в центрі міста, як доказ того, що Китай постійно принижують, бажають образити. А це не забувається і не прощається [14, с. 56-57].

Отже, незважаючи на деякі зусилля, до вирішення проблем патріотичного виховання в Україні ще відсутній комплексний і збалансований підхід. Ще не створена цілісна система, для чого необхідно скоординувати зусилля законодавчої та виконавчої влади, всіх зацікавлених громадських організацій, вітчизняної педагогічної науки.

\section{Jimepamypa}

1. Горбова Н.А. Правова культура та культура прав людини: співвідношення понять та шляхи імплементації. Порівняльно-аналітичне право. № 1. С. 16-18.

2. Горбова Н.А. Формування правової культури: антропологічний підхід. Порівняльно-аналітичне пра Bo. C. $24-27$.

3. Остапович И.Ю. Сущность и особенности неюридической формы воздействия на правотворчество. Мир науки, культуры, образования. 2011. № 4. C. 292-294.

4. Сальников В.П., Степашин С.В., Хабибуллин А.Г. Государственность как феномен и объект типологии: теоретико-методологический анализ. СанктПетербург : Университет, 2001. 208 с.

5. Заздранова О.І. Ідеологія в еволюціонуючому соціумі. Харків : Консум, 1999. 208 с.
6. Duber B. Problematyka narodu jako społeczności ideologicznokulturowej (na przykładzie narodu polskiego). Między Polska a Ukraina: Pograniczemniejszości, wspótpraca regionalna. Rzeszów, 1999. S. $37-43$

7. Недюха М. Правова ідеологія: основні теоретико-методологічні підходи до визначення поняття. Публічне право. 2012. № 3. С. 299-306.

8. Нестеренко О.М. Актуальні проблеми та цілі правового виховання молоді. Науковий вісник Ужгородського національного університету. Серія: Право. 2015. Вип. 35, ч. 2. Т. 1. С. 53-55.

9. Панчук І.О. Особливості правової ідеології у перехідних суспільствах (транзитних демократіях) в контексті досвіду вітчизняного державотворення. Наукові праці МАУП. 2014. Вип. 1 (40). С. 105-110.

10. Кравченко И.И. Власть и общество. Власть. Очерки современной политической философии Запада / отв. ред. В.В. Мшвениерадзе. Москва : Наука, 1989. C. $37-64$.

11. Клименко А.И. Правовая идеология в контексте пространственно-временных характеристик современного общества. Пространство и Время. 2012. № 4. C. $36-41$.

12. Якубенко К.Ю. Формирование арабо-исламской политической идеологии (VIII-XIV вв.). Сибирский юридический вестник. 2008. № 4. С. 13-21.

13. Гаджиев К.С. Тоталитаризм как феномен ХХ века. Вопросы философии. 1992. № 2. С. 3-25.

14. Баранов В.М. О правовой демагогии. Право. Власть. Законность. Нижегородские юридические записки. 1997. Вып. 3. С. 10-28.

15. Мовсесян А.Г. 0 форме и содержании. Нужна ли идеология рыночной экономике. Независимая газета. 1998.17 июля. С. 3.

16. Афанасьєва Ю.В. Закордонний досвід патріотичного виховання. Актуальні проблеми державного управління. 2017. № 2 (52). С. 1-5.

17. Діденко О.Г. Зарубіжний досвід патріотичного виховання громадян та можливості його адаптації в Україні. Аспекти публічного управління. 2014. № 3-4. C. $52-59$.

\section{Анотація}

Нестеренко О. М., Горбова Н. А. Теоретикометодологічні механізми впливу державної політики на процес формування свідомої особистості. - Стаття.

У статті розглянуті теоретико-методологічні механізми впливу державної політики на процес формування свідомої особистості. Необхідність досягнення ефективності правових інститутів вимагає, щоб правова доктрина вбирала в себе результати всебічного дослідження як ідеологічного, так і історико-культурного аспектів юридичних конструкцій. Панівна у державі ідеологія багато в чому визначає характер правосвідомості, правової культури, а відтак - і правового виховання, спрямованого на прищеплення громадянам відповідних цінностей і думок. Найбільш потужним вплив ідеології на свідомість населення є у державах недемократичного вектору розвитку.

Стан і характер виховання молодого покоління визначаються економічними, соціальними, культурними й історичними умовами суспільного розвитку, які склалися в різних країнах. Підходи до розвитку патріотизму у громадян на кожному етапі становлення і розвитку тієї чи іншої держави зазнають змін відповідно до розроблених і прийнятих філософських концепцій, педагогічних теорій, а також вимог суспільства до організації виховної діяльності. Попри те, що патріотизм 
$є$ універсальним явищем, у різних типах правових систем існують різні підходи до його виховання.

Вивчення механізмів формування та впливу правової культури і правової ідеології має істотне значення для прояснення механізму наступності та формування інновацій у правових системах, розкриття ідейних підстав інтеграції професійної і суспільної правосвідомості. Правова ідеологія об'єктивує право, перетворює його з продукту інтерсуб'єктивної соціальної взаємодії у відносно самостійний, об'єктивно існуючий регулятор, який накладає на адресатів стандарти належної поведінки.

Отже, незважаючи на деякі зусилля, до вирішення проблем патріотичного виховання в Україні ще відсутній комплексний і збалансований підхід. Ще не створена цілісна система, для чого необхідно скоординувати зусилля законодавчої та виконавчої влади, всіх зацікавлених громадських організацій, вітчизняної педагогічної науки.

Ключові слова: ідея права, правова доктрина, правова ідеологія, правова культура, правова система, юридична догматика.

\section{Summary}

Nesterenko O. M., Gorbova N. A. Theoretical and methodological mechanisms of influence of public policy on the process of formation of conscious personality. - Article.

The article deals with theoretical and methodological mechanisms of influence of public policy on the process of formation of conscious personality. The need to achieve the effectiveness of legal institutions requires that the legal doctrine incorporates the results of a comprehensive study of both the ideological and historical-cultural aspects of legal structures. The ideology prevailing in the state largely determines the nature of justice, legal culture, and therefore legal education aimed at imparting to the citizens relevant values and thoughts.
The ideology prevailing in the state largely determines the nature of justice, legal culture, and thus legal education aimed at imparting to the citizens relevant values and opinions. The most powerful influence of ideology on the consciousness of the population is in the states of the undemocratic vector of development.

The state and nature of the upbringing of the young generation are determined by the economic, social, cultural and historical conditions of social development that have developed in different countries. Approaches to the development of patriotism in citizens at every stage of formation and development of a state undergo changes in accordance with the developed and accepted philosophical concepts, pedagogical theories, as well as the requirements of society for the organization of educational activities. Although patriotism is a universal phenomenon, different types of legal systems have different approaches to nurturing it.

Studying the mechanisms of formation and influence of legal culture and legal ideology is essential to clarify the mechanism of continuity and formation of innovations in legal systems, to reveal the ideological grounds for the integration of professional and social justice. Legal ideology objects the law, transforms it from the product of intersubjective social interaction into a relatively independent, objectively existing regulator that imposes on the addressees standards of good behavior.

Thus, despite some efforts to address the problems of patriotic education in Ukraine, there is still no comprehensive and balanced approach to addressing these challenges. A coherent system has not yet been established, for which it is necessary to coordinate the efforts of the legislative and executive power, all interested public organizations, national pedagogical science.

Key words: idea of law, legal doctrine, legal ideology, legal culture, legal system, legal dogma. 